\title{
THE ENGLISH ORIGINS OF GEOTOURISM (AS A VEHICLE FOR GEOCONSERVATION) AND THEIR RELEVANCE TO CURRENT STUDIES
}

\author{
Thomas A. Hose
}

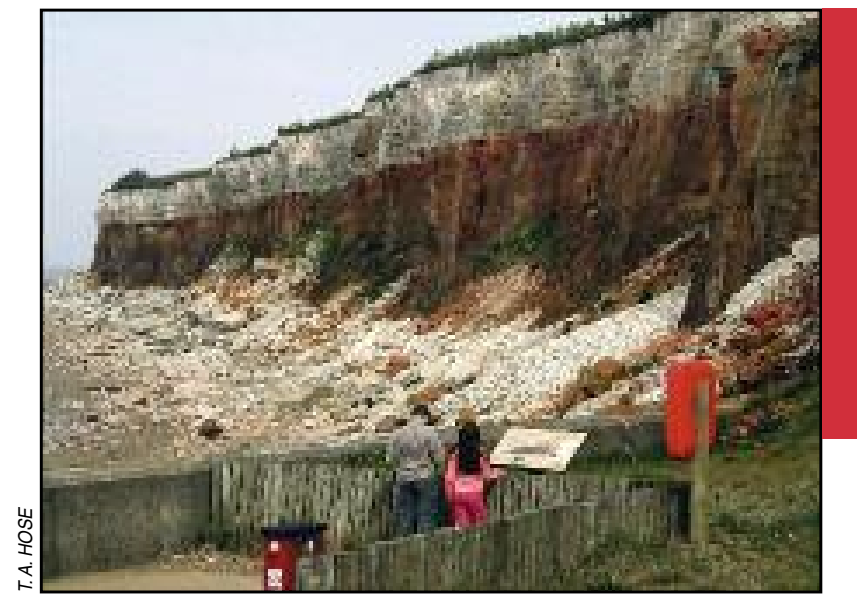

Hunstanton, Norfolk - the beach and interpretative geology panel in April 2003. Note the striped Carstone (Middle Albian), Red Chalk of the Hunstanton Formation (Cenomanian) and West Melbury Marly Chalk Formation (Cenomanian) sea cliffs and the interpretative panel (designed for English Nature by the Centre for Environmental Interpretation in the early 1990s. Steps near this panel situated at the northern end of the concrete promenade that protects the small day-tourist resort of Hunstanton give access to the beach.

The active nature of the cliff falls prompted the local authority to erect (just out of camera shot) a very large and visually intrusive warning sign! 


\title{
The English Origins of Geotourism (as a Vehicle for Geoconservation) and Their Relevance to Current Studies
}

DOI: $10.3986 /$ AGS51302

UDC: 55:338.483(410.1)

COBISS: 1.01

\begin{abstract}
This paper contextualises the recognition of the geotourism concept. It stresses the underpinning geoconservation purpose that drove its development in England. It notes the multidisciplinary nature of geotourism research. It provides a summary of the development of early modern geoconservation in England as a necessary precursor to the inception, recognition and development of geotourism. It notes the evolving geotourism research approach and its impact on its understandings, definitions and models; the whole is contextualised within the framework of special interest tourism. The interaction between geotourism and geoparks is considered. A new geotourism definition is provided and a plea made for its original rationale and observations to be included in studies elsewhere in Europe.
\end{abstract}

KEY WORDS: geotourism, geoconservation, geosite, geoheritage, geoparks, England

The article was submitted for publication on February 2, 2011.

\section{ADDRESS:}

Thomas A. Hose, Ph. D.

Rockhounds Welcome!

Chalton, Bedfordshire, LU4 9UT, United Kingdom.

E-mail: t.hose123@btinternet.com

\section{Contents}

1 Introduction - the initial thoughts on the geotourism concept $\quad 345$

2 The background to geoconservation in England 346

3 The geotourism concept's emergence $\quad 348$

4 Geoconservation as a necessary precursor to geotourism

5 Defining and contextualising geotourism within environmental interpretation $\quad 352$

$6 \quad$ Geotourism and geoparks 353

$7 \quad$ Geotourism as a special form of tourism $\quad 354$

8 Conclusion - geotourism and geoconservation or geo-exploitation? 354

9 References 357 


\section{Introduction - the initial thoughts on the geotourism concept}

As initially envisaged in the United Kingdom by the author (Hose 1995a, 2003) the inception and study of geotourism was developed as a way for geology and geomorphology to be promoted in order to identify, protect and conserve their geosites by: generating public and political support - that is constituency building; generating funding for geoconservation; emphasising their contribution to, and integration within, the global geoscience community; thus recognising and promoting their regional, national and international geoscientific significance. This approach followed the recognition that geosites, in areas of England well known to the author over some twenty years, were seemingly poorly understood and undervalued by their local populations and landowners; consequently they had, and increasingly from the 1980s, often been lost to detrimental other uses with little or no public outcry. Hence it seemed desirable and opportune, as a means to preserve geosites for the future, to develop some means of explaining and promoting their significance. At the outset it was recognised that geotourism provision would require the:

- Identification and conservation of its resource base; geosite inventories (Wimbledon 1996a) and their statutory protection (Wimbledon 1996b) subsumed within geoconservation.

- Acquisition of knowledge and understanding of geosite users and visitor bases, subsumed within 'visitor studies', by field surveys would be needed.

Development and promotion of effective educational (Gonggrijp 1997) and interpretative media, subsumed within media evaluation and visitor studies, by field and desktop study and analyses would be needed; effective interpretative provision could only be developed when user characteristics were known and understood, informing the location, selection, content and design of such media.

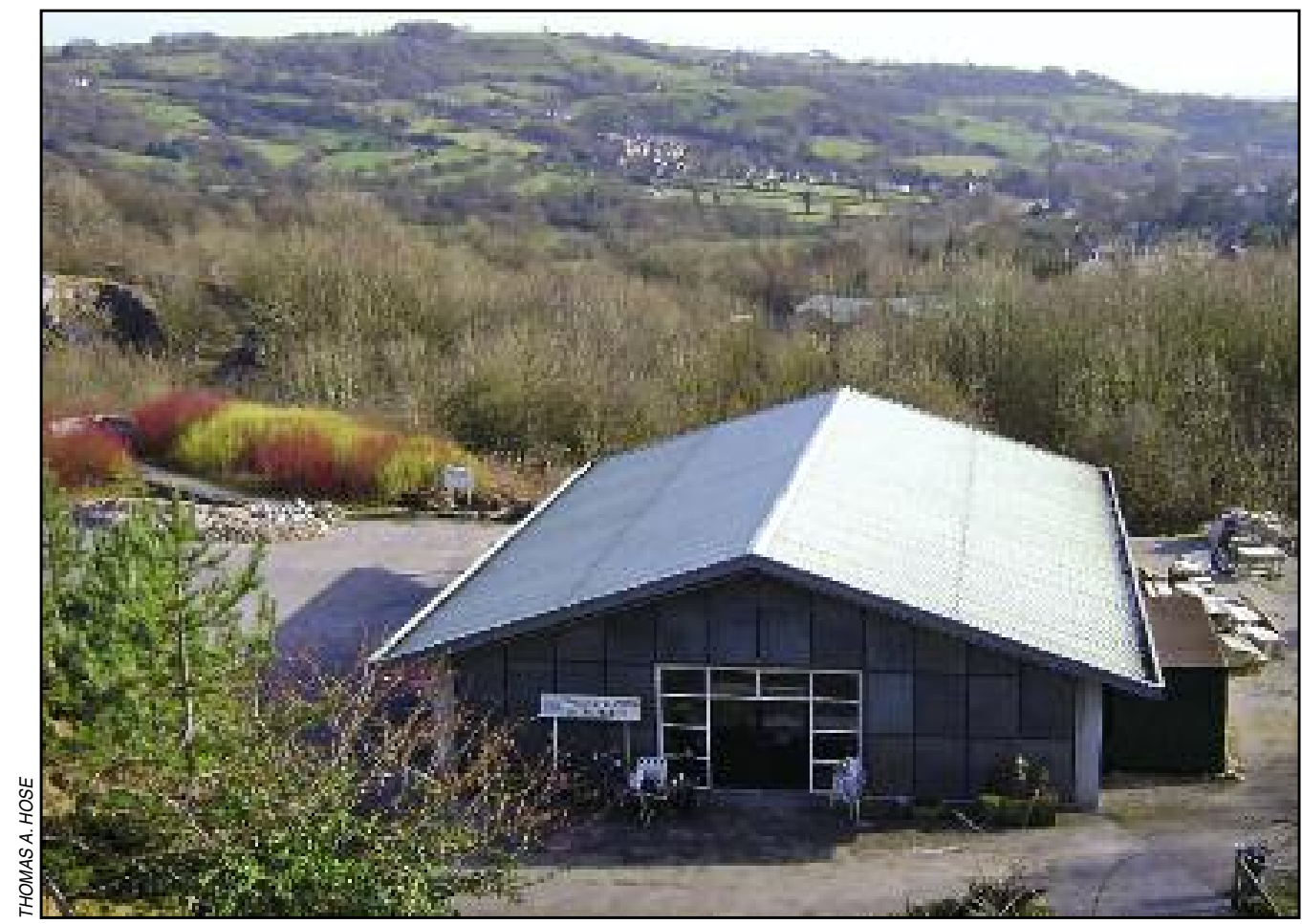

Figure 1: The National Stone Centre, Wirksworth in the Peak District (in May 2005). Note the visitor centre and children's activities area to its right. To the left of the building can be seen the beginning of the geology trail and one of its quarry outcrops. In front of the building erected in the late 1980s, that houses a shop and exhibition, is the informal extension to its café. The white Lower Carboniferous limestones of the Centre contrast with the dark stone walls on the rolling hills behind (and to the south of) of sandstones and greywackes from the Millstone Grit Group (Namurian, Upper Carboniferous). 
Consequently it seemed that the competent evaluation and research of geotourism provision required a multidisciplinary approach. It was also obvious that sound geoscience knowledge and field expertise were necessary researcher attributes; likewise a knowledge and application of social science, tourism and geographical methodologies was deemed essential. Fortunately, the author's undergraduate and postgraduate education and professional engagement in schools, museums and higher education work in leisure and tourism, enabled him to conduct the wide-ranging study, although this necessarily extended over several years. Initially the study was designed to focus on geosite visitors and then moved onto the evaluation of interpretative and promotional media. The former began with a visitor survey (Hose 1994a, 1995b) in 1994 at Hunstanton (Figure 1) on the North Norfolk coast. The latter particularly began in 1994 at the National Stone Centre (Hose 1994b) in the Peak District and was further developed at the Charmouth Heritage Coast Centre in the same year. It later considered a broader range of topics including the evaluation of museum exhibitions, such as at Ludlow (Hose 1997a) in the Welsh Borderland, and the historical development of landscape tourism (Hose 2008). In order to gain political and public acceptance of geotourism, and to generate funding and support in kind from potential partners, it was appreciated by the author that tangible benefits had to be indicated; these were initially suggested as the development of an: innovative area of academic study within the discipline of tourism; suite of evaluation and analytical tools to assess the competence of geotourism provision; new tourism products in old mining and heavy industry areas and thereby provide employment; extended tourism season in coastal resorts and inland tourism centres. The preservation of geosites was therefore considered to necessitate constituency-building by the geoscience community with politicians, planners and developers. This it was thought could best be achieved by demonstrating their existing benefits, heritage tourism potential and crucially their economic worth when retained for both tourism and other recreational purposes. Consequently there was an early emphasis in the study on populist publication and dissemination of the findings at both academic and practitioner gatherings. The following account summarises some of the key aspects of the development and promotion of the geotourism concept.

\section{The background to geoconservation in england}

To understand the rationale of the 1990s inception, development and definition of geotourism, with an underlying geoconservation purpose, in the United Kingdom (UK) it is necessary to appreciate the situation of geosites in England in the preceding two decades. These geosites, both geological and geomorphological, had a long history of academic study and relatively ready student access until from the 1970s onwards there were significant changes in the country's economy, higher education sector, and the extractive industry's approaches to security and health and safety matters. Consequence there had been no prior imperative for geoconservation measures, except at a few sites of international significance and these had generally been designated as either National Nature Reserves (NNRs) or Sites of Special Scientific Interest (SSSIs) designated (or confirmed for older localities designated under the National Parks and Access to the Countryside Act, 1949) under the Wildlife and Countryside Act, 1981. The first geological NNR in England, in 1956, was the Wren's Nest (Figure 2) near Dudley in the West Midlands; this is a series of quarries and underground limestone mines formerly worked for the needs of local iron and steel smelting. The Wren's Nest was amongst the first geosites interpreted (Nature Conservancy Council, 1970; Hamblin, Warwick and White 1978) by a UK national conservation agency. Similar provision (Lawson 1977) had been made in the Mortimer Forest (Figure 3), near Ludlow in the Welsh Borderland in the mid-1970s; this was innovative in that it linked several small geosites (Lawson 1973), most of which were not designated as SSSIs, as a linear trail. Whilst limestone and coal extraction in the Wren's Nest area had ceased by the 1960s, iron and steel smelting continued into the 1970s; that iron and steel site is now the Merry Hill regional shopping precinct. Thus the area represents a microcosm of the interplay of geoconservation and geotourism, in relation to the local socio-economic conditions, and as such was included in the author's major ground-breaking geotourism study (Hose 2003) that had evolved from similar work in the Peak District and Norfolk at interpreted geosites.

By the close of the 1970s the negative impact of the UK's economic downturn of that decade on the construction and metal refining industries, as well as the road metal sector, had begun to see reduced mining 


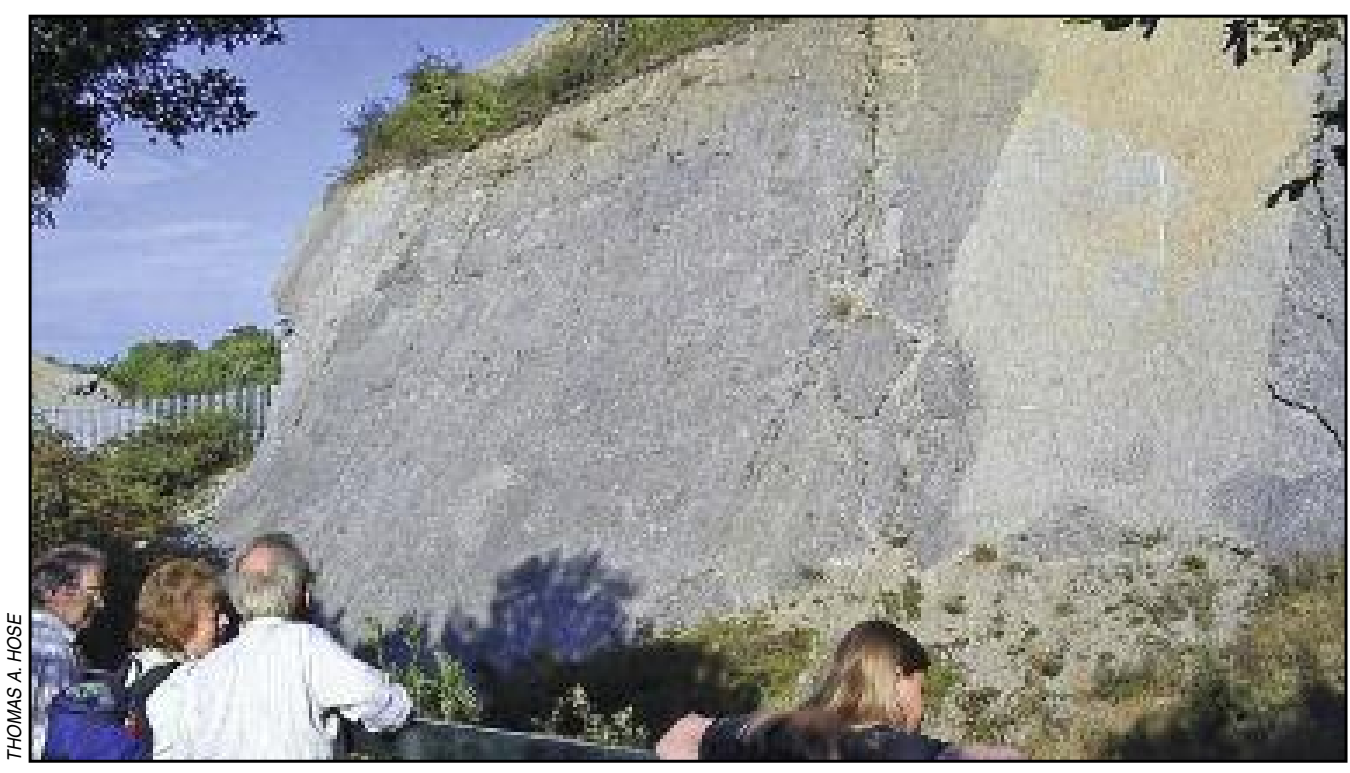

Figure 2: The Wren's Nest National Nature Reserve - the ripple beds (in September 2004). Note the steeply dipping fossil-rich Silurian limestones and mudstones formed on a tropical sea floor. The ripple beds are a very obvious feature but are unstable; the lighter area in the cliff face marks where the rocks have slipped away, necessitating the erection of 2-metre high metal safety fences (to be seen bottom right) to keep visitors away. The wooden viewing platform has a small interpretative panel and provides an excellent vantage point from which to photograph the feature.

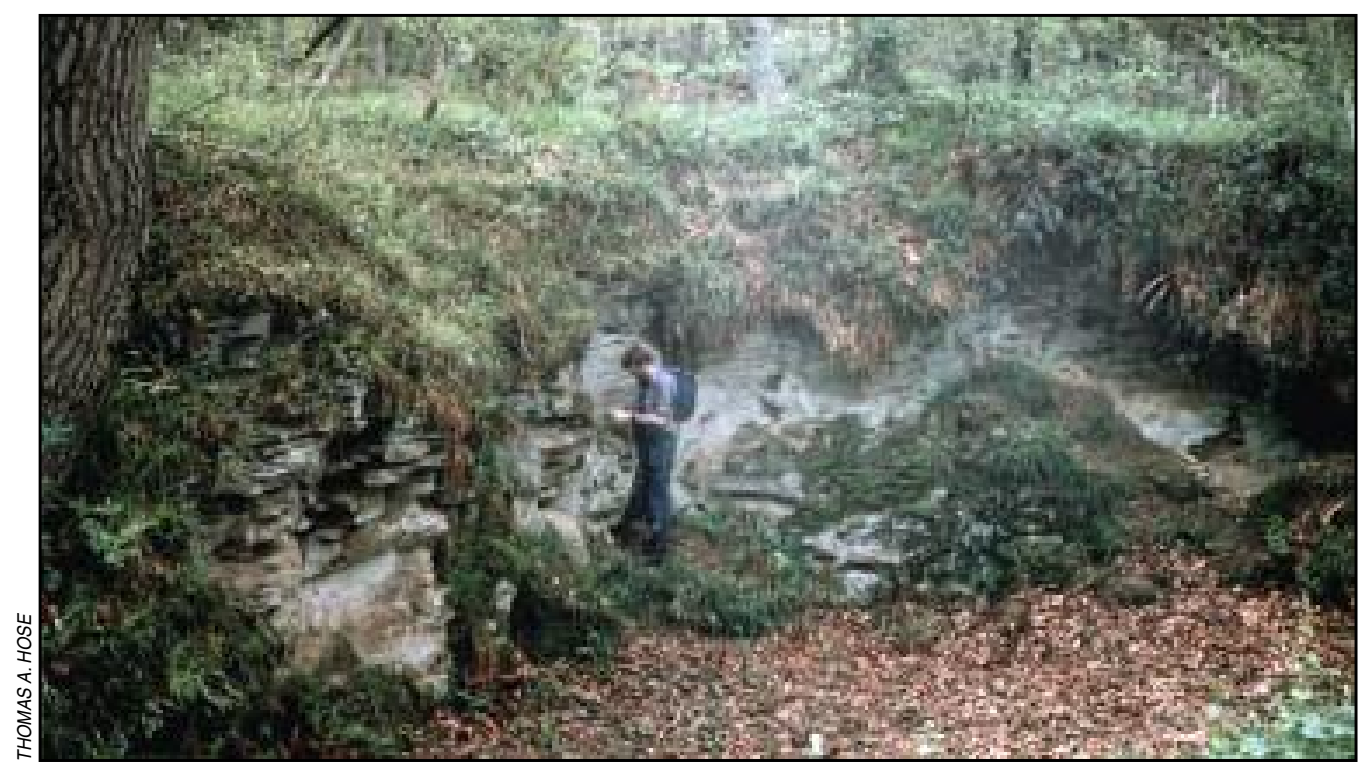

Figure 3: The Mortimer Forest Geology (Location 12) Trail, near Ludlow in the Welsh Borderland (in mid 1997). Note the gently dipping Upper Silurian medium grey to greenish grey, flaggy siltstones of the Lower Whitcliffe Formation, Ludlow Series in this small old roadside quarry. The challenge of maintaining access to the rock faces in such a small quarry is highlighted by the overgrowth of algae, lichen, and mosses; the growth of ground ivy, and bracken, together with the soil and vegetation creep from the hillside above can also be noted. Not so obvious is that the orientation of this quarry and the mixed deciduous and evergreen tree cover means that it is in shade and shadow for much of the day making photography difficult. Its entrance is marked by a numbered post and its geology is described in an illustrated A5 trail booklet. 
and quarrying activity with the associated loss of many geosites. Also by then, access into many disused geosites was lost due to their physical degradation and the increasing restrictions on admittance due to security and health and safety measures. Concomitantly, there was also developing political pressure to return to new uses redundant mines, quarries and associated heavy industry sites. Local Government and development agency involvement and expenditure on land reclamation and amenity landscaping (Culshaw et al. 1987) accelerated on the grounds of removing the blight of industrial dereliction recognised as an issue a decade earlier (Oxenham 1966) and returning sites to aesthetic after-use such as amenity, agriculture, housing, light industry and nature conservation. Hiding the scars of past industrial extraction and exploitation meant masking and burying the evidence of such landscapes, rather than conserving and promoting their scientific and societal significance; this was all part of the strategy of attracting new cleaner light industry and other inward economic investment to old industrial areas (Kotler, Haider and Rein 1993; Ward, 1998). Overlaying all of these issues and approaches was the development and rapid expansion of the industrial heritage sector (Alfrey and Putnam 1992; Cossons 1974) in England. This found new uses for old industrial buildings and employment for many of those displaced from traditional heavy industries, as well as providing training and employment for school and college leavers. Central Government through various training and employment schemes and its conservation agencies managed and/or funded the sector's development, often in partnership with museum and heritage trusts.

In many industrial heritage schemes the statutory national historic preservation body, English Heritage, supported the preservation of industrial and mining buildings, but the statutory national nature conservation body, English Nature, actually destroyed the associated quarries, mines and spoil heaps - despite the advice and strategy (Nature Conservancy Council 1990) from its predecessor - by landscaping and planting over them. A good example of this is the Snailbeach, Shropshire lead and barites mining complex; it actually gained several conservation and tourism awards! Again, at the National Coal Mining Museum near Wakefield, West Yorkshire, in the 1980s the management and interpretation focus was on social and industrial history with no real mention of its geological basis. Belatedly in the early 1990s, the worth of such landscapes and their associated features was finally recognised as holistically integral (Durham County Council 1994). However, the conservation of key features in quarries required somewhat earlier input into the aftercare management process than had been previously considered by most geologists (Wright 1993). Geosites were commonly seen at the time as merely the basis for new forms of bioconservation and promotion, especially through the establishment of wildlife centres and nature trails.

\section{The geotourism concept's emergence}

To the author it seemed likely that many geosite losses, and especially the ones with which he was personally familiar in England's Peak District, Welsh Borderland and West Midlands were at least partly because the geoscience community had failed to constituency-build in the wider political, planning and public communities. This became especially apparent to the author from his experiences in the Peak District over some twenty years. He had been introduced to the Ashover area, well known to British geology students from the late 1950s because of a major fieldwork text that was in use up to the 1980s (Himus and Sweeting 1972), on an undergraduate geology field mapping course. Not too far away, and with some similarities of structure and geology, is the Crich area which the author field mapped as an undergraduate; its limestone quarries in particular were virtually obliterated or access made difficult by landfill and restoration schemes together with new recreational uses from the late 1970s onwards. This issue was initially highlighted when as a secondary geography school teacher he witnessed the virtual obliteration of the coal mining industry in County Durham. The closure and almost immediate demolition of Blackhall Colliery in 1984 is a case I point; all that remains today, with the site landscaped and used for a light industry estate is the pit-head winding wheel on a brick plinth (Figure 4) as a monument. This issue was further highlighted when, as a secondary school head of geology, he led field trips to the Peak District in the mid-1980s and was taken aback at the nature and scale of the loss; for example, the infilling of the St. Michael's Quarry at Crich (Figure 5) that was completed in the 1990s leaving no surface trace of the quarry (Figure 6). By then the geology field-guides (for example, Cope 1972, 1976; Neves and Downie 1967; Simpson 1982) for the area included several accounts of geosites that were also no longer available or readily accessible. What appalled him most was the seeming local acceptance, bordering on the enthusiastic, of the need for this restoration 


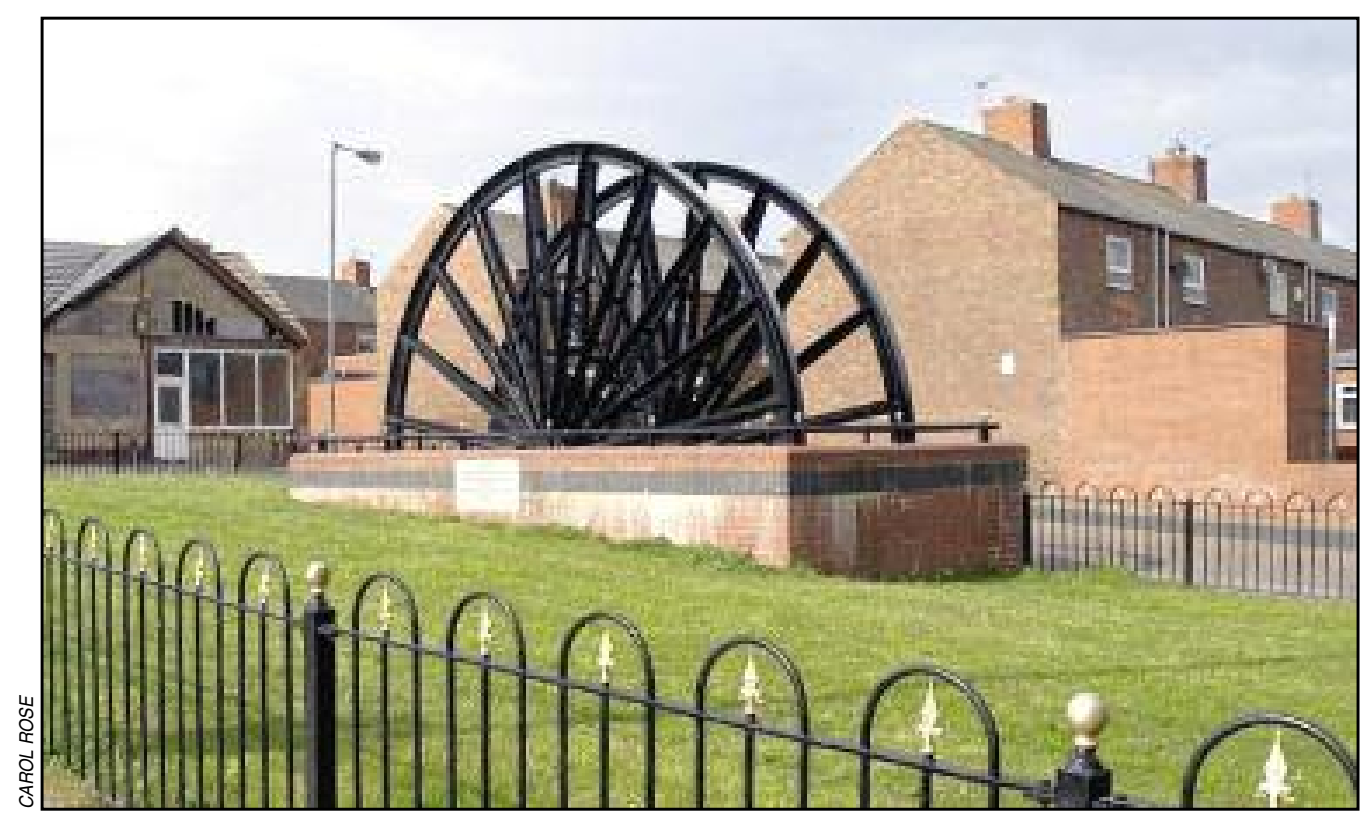

Figure 4: Blackhall Colliery, County Durham, north-east England - Colliery pitwheel industrial monument (in April 2007). houses, with its large wheels, is partly demolished. The white mound to the right probably marks all that was left of.

in an area that formerly had quarrying and associated processing industries as a major economic activity; this reflected the growing 'gentrification' of the countryside and the rise of 'neo-romanticism' (Hose 2008). Coincidentally, the Peak District is where the beginnings of historic geotourism can be traced (Hose, 2008). It was the first region in England to be explored, from the late seventeenth century onwards, by travellers visiting its numerous caves and mines. Not much later, they were also visiting potteries, mills and factories, much as today's heritage tourists visit its industrial archaeology sites (Nixon 1969; Harris 1972) and country houses. Major reasons for its involvement in both historical and modern geotourism are its, sometimes even when quarried as at Crich (Figure 7), aesthetic landscapes and varied well-exposed geology of long-standing economic significance. It is also surrounded by several major urban centres whose population visit it for amenity purposes.

Since the industrial heritage sector and its industrial archaeologists had in a very few years, from its inception in the 1960s and acceptance as an academic discipline in the 1980s, succeeded in constituency-building for perhaps something could be learned from its experience for geoconservation. It seemed that geoscientists were either unable or unwilling to engage with, or communicate to, a wider audience than themselves the scientific and societal significance of geosites. This led the author to develop a research programme on 'site specific geologic interpretation'. This initially evaluated some early examples of geological interpretation provision by English Nature (Page 1994) at Hunstanton in Norfolk (Hose 1994b; 1995b; 1996a) and then at the National Stone Centre (Thomas and Prentice, 1994) (Hose 1994b) at Wirksworth in the southern Peak District. Finally it led to a dedicated geotourism research programme (Hose 2003) that examined and published (Hose 1996b, 1996c, 1997a, 1998a, 2005a) on two classic geological regions of English. The challenge of promoting geoconservation through geotourism was eventually noted by some UK geoconservationists who recognised: »... the sense of loss which would be felt if an important geological feature was damaged or destroyed ... would be minimal. Contrast this with the loss of a much-loved hay meadow or bluebell wood. The response has a great deal to do with the value which the community ascribe to the various elements of their local environment." (McKirdy and Threadgould 1994, 459). Geotourism was indirectly promoted by the UK's first geoconservation strategy that had amongst its projected outcomes: »... providing opportunities for properly controlled leisure pursuits such as caving, the study of fossils and minerals and industrial archaeology of old mining sites." (Durham County Council 1994, 5). 


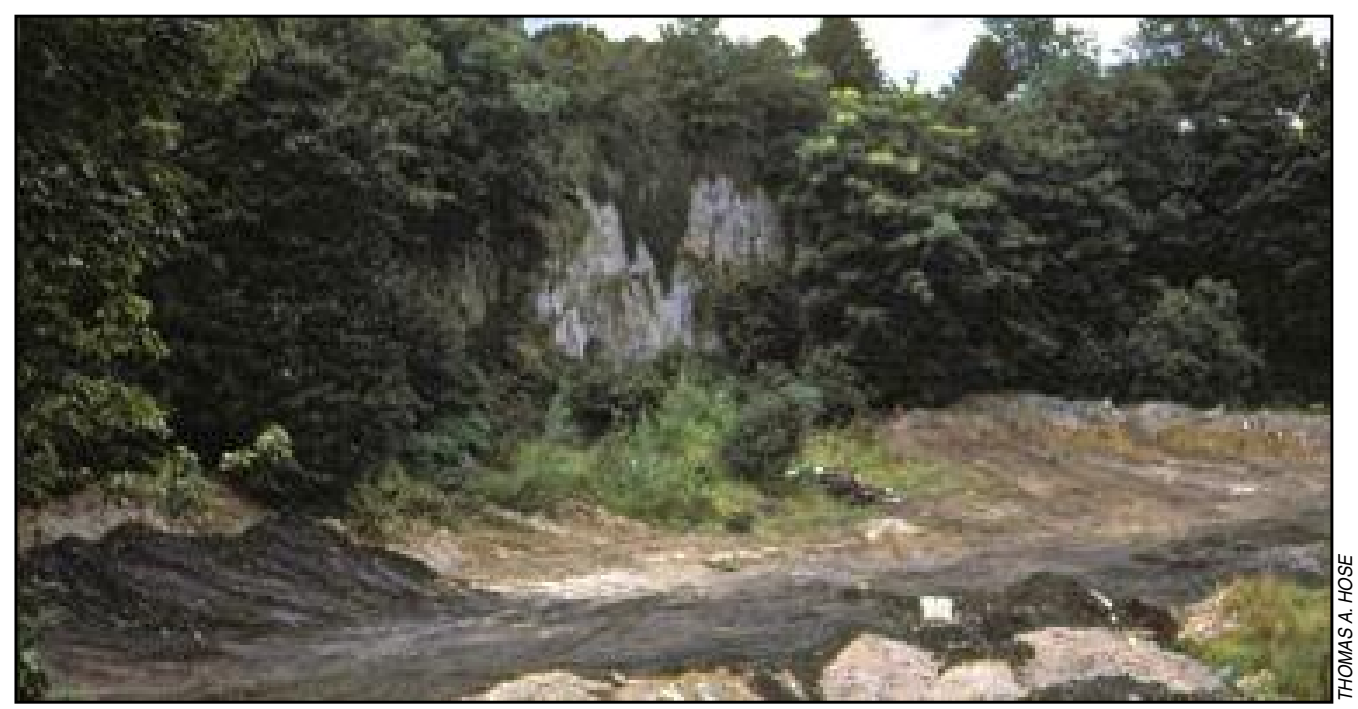

Figure 5: St Michael's Quarry, Crich in the Peak District - during its infilling (in September 1986). Note the church building, which gave its name to this former limestone quarry, is just visible above the trees just left of centre; these trees hide the road that runs above the quarry alongside the church. At the foot of the large quarry face in Lower Carboniferous limestone (formerly the Matlock Group and now included in the Monsal Dale Limestone Formation) there was formerly exposed a rich fossil coral bed, by then buried in the initial landfill operation. The size of the deciduous trees growing in the quarry floor give some indication that this quarry had been disused for at least forty years prior to the landfilling. It was fairly accessible to geologists for many years, although the original entry route through a tunnel had long been enclosed by a private garden, via a downslope path to the right. During the landfilling operation access to geologists was denied and no \{rescue' in-situ recording or collecting of geological material from strata soon to be no longer readily accessible in the district was possible.

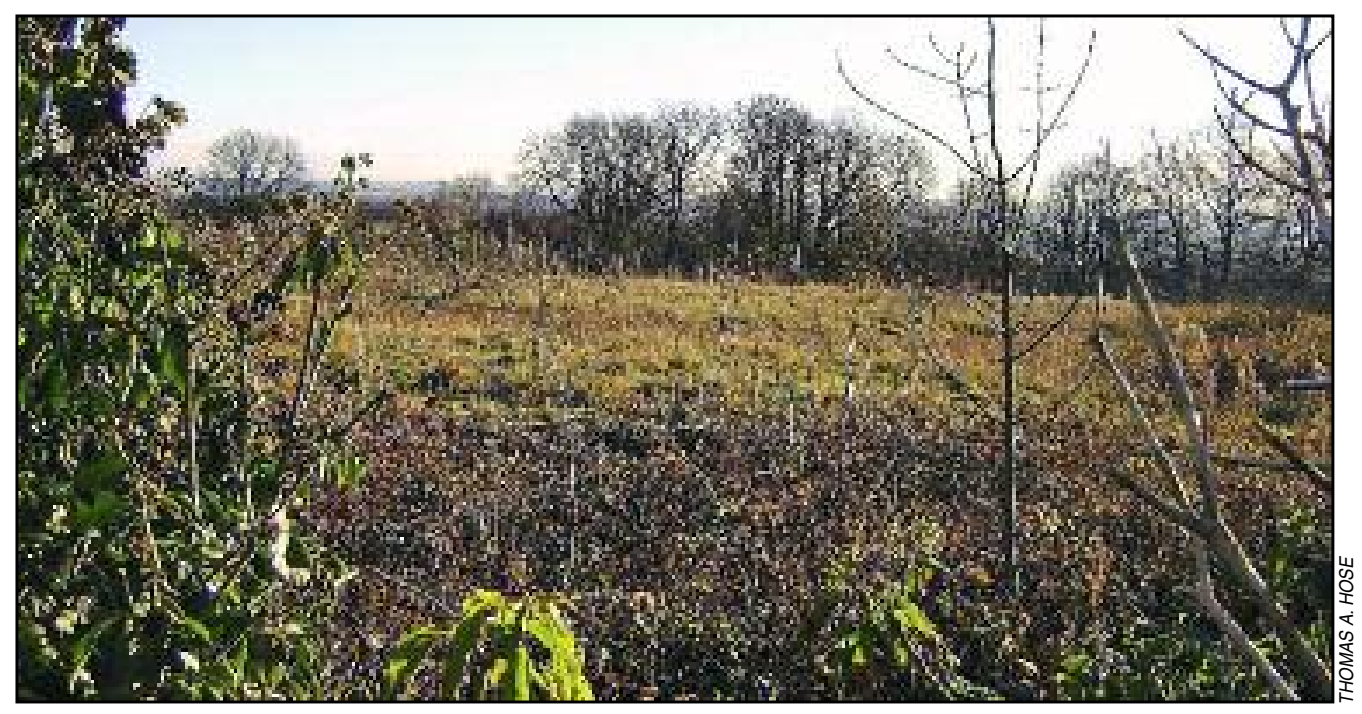

Figure 6: St Michael's Quarry, Crich in the Peak District - after its infilling (in November 2010). This view is taken from the road that runs alongside the church and in the past above the now completely buried cliff (seen in Figure 13) of the former quarry. It is obvious that the quarry has been completely infilled and the former slope of the hill has been more or less restored to its original profile. The only evidence of the old quarry is the decaying fence in the nearby corner 50 some metres from the vantage point of this photograph. One of the other larger limestone quarries within 500 metres of this site has also been obliterated and the remaining quarry is partially landfilled and used for motorcycle scrambling events; they provided the only, and now completely lost, exposures of the former Cawdor Group (now included within the Eyam Limestone Formation). 


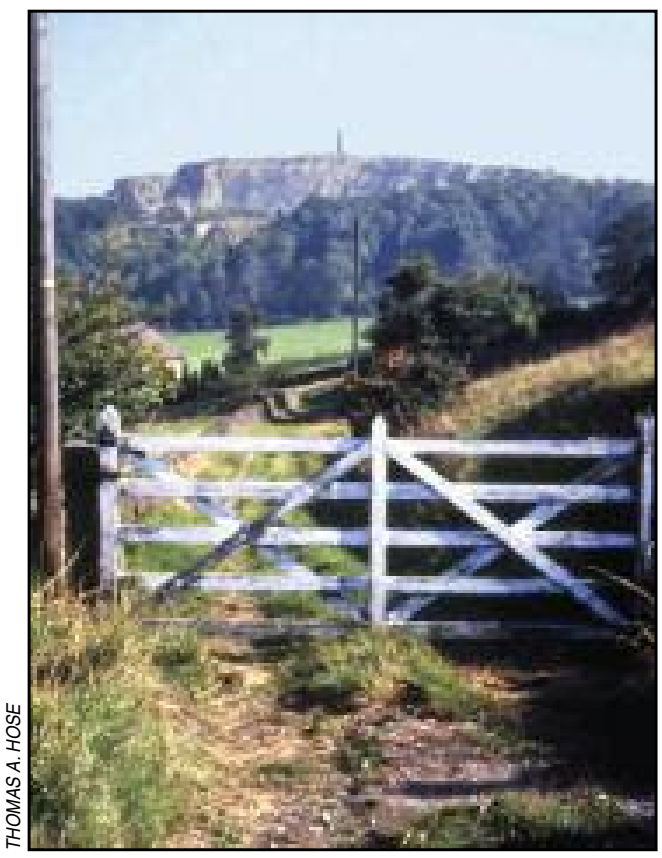

Figure 7: Crich Cliff from Caddington, in the Peak District (in September 1986). The limestone hill in the distance is not a natural exposure; it is large and still working limestone quarry (in the Carboniferous Limestone Matlock Group, now the Monsal Dale Limestone Formation). The hill itself was formerly mined for lead and numerous capped and uncapped mine shafts litter the hillside especially to the left of the tower. The tower is a war memorial erected in the 1930s initially to commemorate the dead of the Great War of the Sherwood Foresters (the local army regiment). The floor of the quarry houses a national tramway museum, originally established in 1959. The middle distance and foreground are in the gentler slopes principally underlain by the Ashover Grit and Chatsworth Grit of the Millstone Grit Group (Namurian, Upper Carboniferous). Overall, despite the quarrying the landscape is not without much aesthetic appeal to day-tourists from the nearby towns.

\section{Geoconservation as a necessary precursor to geotourism}

Geotourism is fundamentally a geosite-based activity. Its modern origins can be traced to the early 1980s when the connection was made by the author between the loss of geosites in England, in the areas in which he had received much if his initial geological field education and subsequent professional involvement, and the probable reasons for the general societal lack of concern over such losses. From the outset it was underpinned by an awareness of the need to communicate geoconservation issues. Despite clear expositions on the need to inform and educate its stakeholders it remains a truism that: »Sadly, many geoscientists fail to see the fundamental supportive role of geosite conservation. Its role is to keep available the vital site resource that our community needs for future research, as well as for education and training. In essence, it is a simple principle, - no sites, no science. Geoconservation is essential to maintaining the best of our geoscience heritage. (Wimbledon et al. 2000, 69).

Geoconservation is defined by the author as: »The dynamic preservation and maintenance of geological and geomorphological sites, coupled with their associated collections of specimens and archive materials « (Hose, 2003). It attained some common professional usage in the 1980s and later gained UK credibility with the 1998 renaming of the Geological Society of London's Geological Conservation Committee to the GeoConservation Commission; this had the remit to: »... promote the conservation of Earth heritage and to ensure that we pass it on in good order to future generations for investigation, education and enjoyment." (Geological Society nd, 2). The author's geoconservation interest was partly informed by his involvement, in the late-1970s, as a museum natural historian, in the mainly museum administered National Scheme for Geological Site Documentation (NSGSD); this had been launched after a meeting in Sheffield in 1977. He had established one of its Geological Locality Records Centres. The NSGSD had its origins in the 1974 inauguration of the Geological Curators' Group (GCG) which included members from national, local authority and university museums; its original constitution included as one of its aims: »... the advancement of the documentation of and conservation of geological sites «. Through its 53 Geological Locality Records Centres it amassed some 20,000 records (Stanley 1993). Since the early 1970s there had been also been in England some limited university sector recognition (Toghill 1972) of the importance of co-operation between land owners/tenants, statutory and voluntary conservation bodies in the Welsh 
Borderland; long experience there (Anon 1976; Toghill 1994) highlighted how these maintained access to geosites as well as preventing their physical loss. The area had long been popular for school and university party geology field-trips. Hence by the early 1980s the need to protect geosites had been recognised by the museum and university geological communities. Although much of the early geoconservation focus was on 'hard rock' sites (Allen et al. 1989), the 'soft rock' sites beloved by geomorphologists were not entirely neglected; there was actually a UK national conference (Stevens et al. 1992) on their protection a year before the first UK international geoconservation conference (O'Halloran et al. 1994). Both types of geosite were noted in the world's first national geotourism conference (Hose 1998b; Robinson 1998) in Belfast.

\section{Defining and contextualising geotourism within environmental interpretation}

The first accepted definition of geotourism appeared within a commissioned article for a professional interpretation magazine in 1995 as: »The provision of interpretive and service facilities to enable tourists to acquire knowledge and understanding of the geology and geomorphology of a site (including its contribution to the development of the Earth sciences) beyond the level of mere aesthetic appreciation." (Hose 1995a, 17). It was a development of a working definition for research informally undertaken for English Nature on 'Site-Specific Geological Interpretation': »The promotion and explanation to a non-specialist audience of the geologic features and/or significance of a delimited area by either a fixed facility and/or populist publication. « (Hose 1994b, 2). Both of these early definitions encompassed the examination and understanding of the geosites' physical nature and an examination of their interpretative media and promotion. They also indicated the inclusion within geotourism of the life, work, publications, notes and artwork, correspondence, diaries, collections, workplace, residences and even the final resting places of geoscientists. The former emphasises the traditional resources, collections excepted, of geology and its presentation to the public; most often through guide-books and museum exhibitions. The latter emphasises the human-interest component. Following considerable research the definition was revised to: »The provision of interpretative facilities and services to promote the value and societal benefit geological and geomorphological sites and their materials, and to ensure their conservation, for the use of students, tourists and other casual recreationalists " (Hose 2000a, 136), enshrining the underpinning geoconservation element.

Geotourism, as propounded by the author, is a geology-focussed and visitor-centred development of 'environmental interpretation' or: »... 'the art of explaining the meaning and significance of sites visited by the public'. (Badman 1994, 429). Its relevance to the author's initial geoconservation based approach to geotourism accepts that: »Site interpretation has much to offer the conservation profession and will continue to play a significant role in countryside recreation planning and management.«(Barrow 1993, 278) that has been adopted at geosites (Badman 1994; Keene 1994; Page 1992, 1994; Page et al. 1996; Wray, 1991). Importantly for geotourism: »Environmental interpretation involves translating the technical language of a natural science or a related field into terms and ideas that people who aren't scientists can readily understand. And it involves doing it in a way that's entertaining and interesting to these people." (Ham 1992, 3). The author's major study (Hose 2003) addressed the issues of communicating the technical aspects of geology to non-specialist audiences, particularly through evaluating, often by developing innovative new tools and models (Hose 1997b, 2000a), the communicative competence of geosite interpretative media. The study adopted the 'visitor studies' framework (Bitgood 1988); this seeks to gain an insight into how visitor behaviour impacts upon their learning (Miller 1990) empathetic experience and enjoyment, through their site interaction. Its applied nature is intended to further the enhancement or value-added component of the visitor experience. A well-designed and implemented interpretative programme can match visitors to resources and reduce user conflicts (Sharpe 1982, 14-15); this can only be to the advantage of geoconservation.

Modern UK environmental interpretation began in the mid-1960s (Barrow 1993). Its first major account, in keeping with the geoconservation approach to geotourism, suggested it had: »... the ultimate aim of pointing a conservation message. "(Aldridge 1975, p. 5). The development from the 1980s onwards of the UK's heritage tourism industry promoted interpretation. It drew upon a spectrum of USA pioneered activ- 
ities intended to make a heritage site meaningful to its visitors through: »... enhancing the quality of a heritage site, and contributing to the satisfaction and enjoyment of visitors." (Light 1995, 132). With regard to early UK geoconservation and interpretative provision many countryside visitors were quite well informed about bioconservation having: »... gained their knowledge from the huge expansion in formal and informal education on every aspect of the environment ... many hundreds of local guides to the British countryside which are published each year ... many hours of TV time devoted to this subject.« (Phillips 1989, 127). Hence, the author's initial approach to geotourism study and its dissemination was timely. It was also appropriate in terms of the adopted approaches to promoting natural heritage (bioconservation), and for that matter industrial heritage, conservation as well as bringing geoconservation into line with these disciplines. Within four years geotourism gained national recognition with the world's first dedicated national geotourism conference in Belfast (Hose, 1998b; Robinson, 1998) in 1998. The term was employed nationally (e.g. Anon 1998, 3) and internationally (e.g. Komoo 1997) in several publications in the 1990s, even though these made little or no attempt at an adequate definition. A similar situation is evident with the emergence of geoparks.

\section{Geotourism and geoparks}

The author's initial geotourism approach was incorporated within the UNESCO geoparks programme proposal documentation (Patzak 2000). Thus the influence of a concept developed in England was within a decade being felt across Europe and to some extent globally. Protecting the geoheritage was: »... of special interest to UNESCO due to the fact that it is an excellent tool for educating the broad public in an 'easy manner' about the environment and the Earth sciences. Furthermore, the record of the Earth's history must be conserved because of its ... potential to generate income through sustainable economic development." (Patzak 2009, 36); it is clear that the linkage between interpretation and geoconservation was reaffirmed for geoparks. They were also to be managed holistically to protect and enhance their natural and cultural characteristics. Consequently, they were required to actively participate in the economic development of their territory and its immediate area by working with local small and medium sized enterprises to create and promote new tourism products and services; these could range from interpretative provision to souvenir manufacture. Leisure-related activities, so that its communities recognise and understand their geoheritage and are then keenly involved in its cultural and economic regeneration, are also expected. Despite the caution that: »Rather than exploit this heritage in the non-renewable fashion of the past, there is an opportunity to manage it in a way that conserves it for the future through the development of geotourism.« (McKeever, Zouros and Patzak 2010, 2) there is limited evidence that the geoconservation approach to geotourism is either understood or adopted by the majority of geoparks. The emergence of geoparks as a dominating force in international, if not UK and European, geotourism has placed the original central issue of geoconservation in the forefront. There has been some concern expressed that their development negatively impacts on geosites (Hose 2007a). However, there is still insufficient research, other than anecdotal, on geopark management practices and geoconservation to validate this concern. Examination of numerous world heritage site and geopark (admittedly requiring a lesser standard of geosite significance) proposals and management plans reveals limited explicit mention of geoconservation.

Geoparks are now the UK's major focus for geotourism development. They continue and develop the trends in environmental interpretation, from the earlier recognition of industrial heritage, and geosite promotion. The first in England was the North Pennines in 2003, followed by the Abberley and Malvern Hills in the same year. Shropshire's Welsh Borderland geopark is at the early development stage. Whilst geoparks should be based upon outstanding geology, field observations and their documentation suggests that this can be liberally interpreted. There is ignorance by some writers, especially within the geoparks movement, of the seminal and ongoing work of key European geotourism and geoconservation proponents. This is creating a parochial geopark literature that lacks credibility within the academic geoscience and tourism communities. So imbued is this geoparks' movement with its own achievements it has even attempted to rewrite geotourism's history, erroneously suggesting that: "Geoparks are pioneers in Geotourism ..." (Carvalho and Rodrigues 2009, 7). 


\section{Geotourism as a special form of tourism}

Geotourism at the participant level is 'recreational geology'. It has the potential to extend the tourism season and to enhance the local economy of, and provide additional employment within, participating areas (Hose 1995a). Its success depends upon identifying and promoting its physical basis (geosites) and also knowing and understanding its user base (visitor studies) and developing and promoting effective interpretative and promotional materials (media evaluation) as considered in the previous sections of this paper. It is also worth noting that geotourism can nestle within several emerging forms of tourism. It is a form of 'special interest tourism'; the World Tourism Organisation defines this as: »... specialized tourism involving group or individual tours by people who wish to develop certain interests and visit sites and places connected with a specific subject." (World Tourism Organisation 1985, 3). It happens when tourists' motivations and their associated decision-making are primarily the result of pursuing a specific interest. It also: »... implies 'active' or 'experiential' travel.« (Hall and Weiler 1992, 5). It developed from the 1980s as a legitimate field of tourism studies when significant changes were recognised in the nature of tourism product development and consumption (Krippendorf 1987). The activities undertaken and possible motivations of special interest tourists have been succinctly summarised by Hall and Weiler (1992,3) and discussed, highlighting distinctions between urban and rural and artificial and natural attractions and activities. Much of the discussion is about the concept of special interest travel and the consideration, in effect, of international tourism. This does not preclude its relevance to the domestic market, especially since 'special interest travel' is: »... for people who are going somewhere because they have a particular interest that can be pursued in a particular region or at a particular destination." (Read 1980, 195); this emphasises the centrality of dedicated purpose and place to recreational activity and indirectly suggests that it can also lie within 'niche tourism' (Hose 2005a).

Such changes as Krippendorf (1987) noted also led to the recognition of several other new forms of tourism such as: 'responsible' (Harrison and Husbands 1996); 'sustainable' (Butler 1991), 'alternative' (Gonsalves 1987); 'nature-based' (Richter 1987); and in a more limited manner with 'ecotourism' (Boo 1990). Geotourism with a strong geoconservation element could nestle within all of these with varying degrees of overlap and synergy. For the traditional school and university field parties geotourism can obviously be partly subsumed within 'educational travel' (O'Rourke 1990). However, given its diverse content, and it includes industrial and established cultural elements, the other overarching form of tourism within which geotourism could also be an element is 'heritage tourism' (Boniface and Fowler 1993). The common theme across all of these new forms of tourism, recognised as discrete sub-disciplines of tourism since the 1980s, is their overt requirement of some value-added component and conservation element; inaccurately, for many writers its suggests that they are not forms of 'mass tourism'.

\section{Conclusion - geotourism and geoconservation or geo-exploitation?}

Modern geotourism was demonstrably initiated following the prior emergence of geoconservation. It was first recognised in England from experiences of geosite losses especially within the Peak District and north-east England. It gained widespread UK recognition from the late-1990s. Its antecedents are traceable through several centuries of travel and tourism history (Hose 2008) within the UK region particularly exemplary of such issues, the Peak District. Whilst it is undoubtedly studied as a form of niche or special interest tourism, the understanding of which is given to its participants through environmental interpretation, this does not always mean that mass tourism is not involved. Much of the basic travel and tourism infrastructure enjoyed by geotourists was initially developed for mass tourism. Many mass tourists are given the opportunity to take part in some geotourism activity; for example, the 'Jurassic Coast', a focus of the author's major geotourism study (Hose 1996b, 2003), especially at Charmouth and nearby Lyme Regis along with Lulworth Cove, that seemingly influenced some aspects of its development, but not acknowledged, promotes such engagement. This suggests that in some and an increasing number of instances geotourism provision has moved away from the original underpinning geoconservation approach towards one of geo-exploitation (Hose 2007a) (Figure 8). Despite the author's focus on England, his early study of geotourism actually began, through involvement in commercial and self-organised field-trips, examining a number of European countries for their geology interpretative provision. Hence when approached 


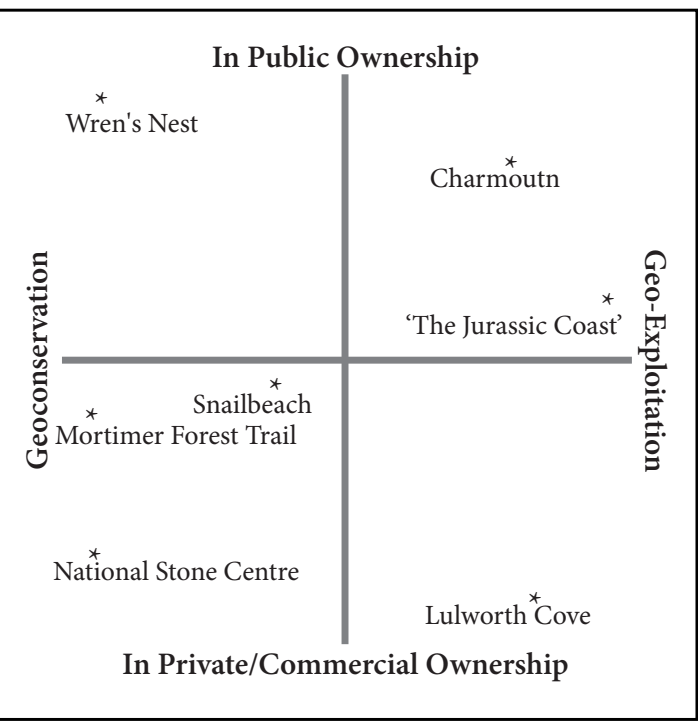

Figure 8: Geo-Exploitation diagram. This qualitatively shows the positioning of some of the key geosites mentioned in the text. It considers geosite ownership and the extent to which they have been protected and conserved; it also considers the emphasis placed on the use and management of geosites.

by a number of agencies and universities in Europe to expound upon geotourism these have additionally informed the more detailed UK studies. Consequently, from first-hand experience the author was able to evaluate interpretative work from the UK applied in the 1990s elsewhere in Europe and for that matter from his studies in the USA (Hose 2000a); for example in Gerolstein, Germany (Rutt 1995). Likewise, the SwabischAlb Geopark in Germany benefited from a combination of UK input (Hose 2000b) and home-grown expertise and similarly when promoting geotourism in Switzerland (Hose 2005b).

The emergence of geoparks has led to several attempts to redefine geotourism. However, not all these attempts focus on the purpose or indeed original nature of geotourism; for example from Poland and those with some engagement with the International Association for Geotourism (IAGt): "Geotourism is an offshoot of cognitive tourism and/or adventure tourism based upon visits to geological objects (geosites) and recognition of geological processes integrated with aesthetic experiences gained by contact with the geosite " (Slomka and Kicinska-Swiderska 2004, 6). However, others from the same background seem to have fully comprehended the need for geoconservation and the original intentions for geotourism: "Geotourism does not only mean aesthetic impressions or briefly learning about the whole area; it is, first of all, the comprehension of its past and of the contemporary processes of transitions and transformations. In this particular range, promoting the knowledge is addressed to local and regional communities, but also to the international societies; it refers to the idea of world systems of conservation and protection « (Alexandrowicz 2006, 9-10). It is perhaps not self evident that within Europe there is an urgent need to agree and promote a definition and understanding that best meets the needs of geoconservationists and the academic/practitioner geoscience communities, as well as being intelligible to tourism and other leisure academics/practitioners, rather than those practitioners seemingly obsessed with geo-exploitation. As has already been shown, geotourism's roots and initial innovations pre-date geoparks. Geoparks anyway were partly based upon the outcomes of the author's research in England and elsewhere incorporated within the UNESCO geopark documentation (Anon, 2000). The key shortcoming of much of the geopark literature is that it derives from practitioner focussed meetings and celebrations of achievements; consequently merely descriptive accounts emerge with little thought to developing an underlying theoretical framework, unlike that of say Hose (2003 2007b) within an accurate historical context or (Alexandrowicz 2006) with a strictly contemporary focus. The former has especially sought to model the way in which geotourism provision is linked both to common tourism infrastructure, geological research and geoconservation, together with interpretative provision (Figure 9). Fortunately, there are some attempts to redress the general imbalance through some basic visitor research (Catana and Rocha 2009), similar to those undertaken 


\section{A Model of Geotourism Development}

Geological Community

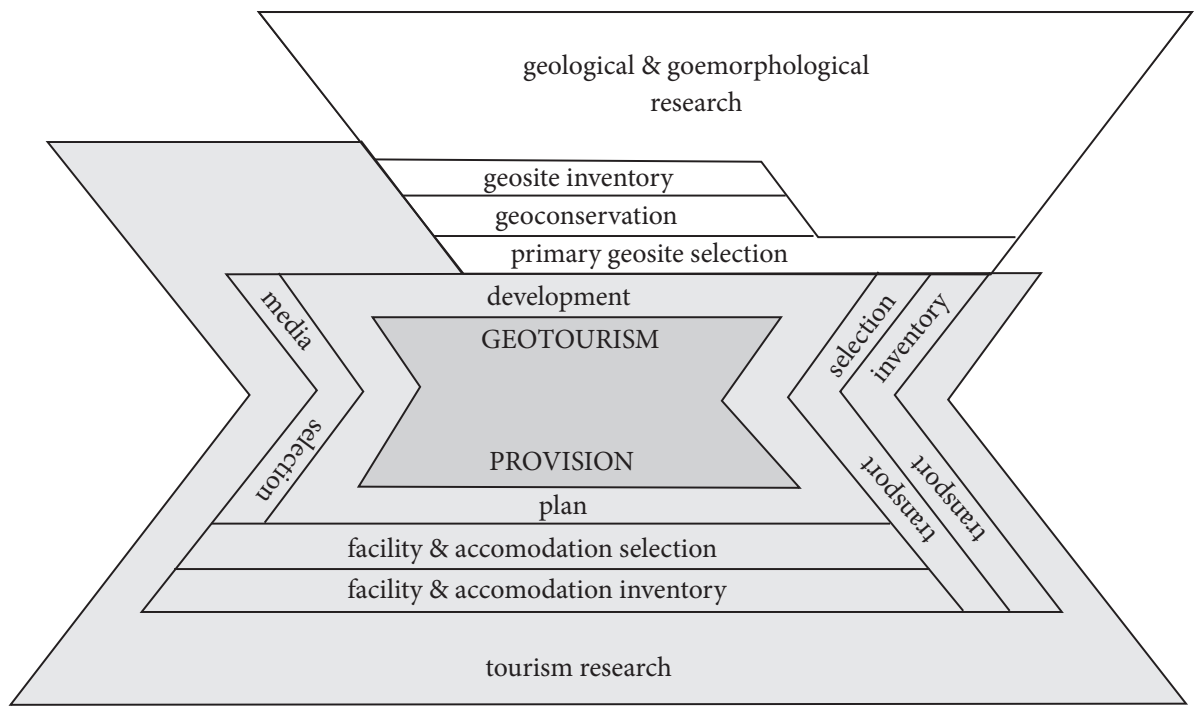

Tourism Community

Figure 9: A Model of Geotourism Development - adapted from Hose (2007b). It draws attention to the major activities and their linear relationships, together with overlapping activities (the narrower lines separate related elements and the broader lines separate distinct sectors). Clearly tourism research underpins traditional tourism elements and should be employed in the selection of primary geosites (such as quarries, mines, cliffs and caves). It draws attention to the way in which geotourism depends upon the availability of traditional tourism infrastructural elements. It indicates that in developing geotourism both tourism and geological stakeholders need to work towards common aims and objectives. It has been slightly modified from the original to indicate the key role of geoconservation.

in the UK in the early 1990s by the author and widely published that has been neglected within many geoparks.

It is a pity that the evaluation tools and lessons learned from their application in England in the development of geotourism have yet to overtly influence UK and European geopark managements. Without this influence the positive impact of geoparks is questionable in appropriately managing, interpreting and promoting a sustainable geoheritage to tourists. It is opportune to succinctly redefine geotourism in the light of the changes in its study and application since the mid-1990s, without neglecting the fundamental underpinning of geoconservation, as the: » The promotion to visitors of interpreted geosites, and their associated artefacts whether on or off site, to ensure their protection and conservation through sustainable management for the purposes of appreciation, enjoyment, education and research by future generations." Whilst research and publication on geotourism has happily spread well beyond the shores of England, its English roots and rationale can still provide the necessary academic and real-world underpinning. To ignore them could lead to the wasteful repetition of research effort, confusion as to the nature and purpose of geotourism, neglect of the crucial importance of geoconservation, and an emphasis on descriptive rather than analytical published studies that do little to advance its academic credibility. 


\section{References}

Aldridge, D. 1975: Guide to Countryside Interpretation: Principles of Countryside Interpretation and Interpretive Planning. Edinburgh.

Alexandrowicz, Z. 2006: Geopark - nature protection category aiding the promotion of geotourism (Polish Perspectives). Geoturystyka 5, 3-12.

Alfrey, J. and Putnam, T. 1992: The Industrial Heritage: Managing resources and uses. London.

Allen, P., Benton, M. J., Black, G. P., Cleal, C. J., Evans, K. M., Jusypiw, S. I., Rowlands, M. A. and Westoll, T. S. 1989: The Future Of Earth Sciences Site Conservation. Geological Curator 5-3. Liverpool.

Field facilities in geology - Mortimer Forest Clearance Project. Earth Science Conservation 11, 1976. Belfast.

Towards An Education Strategy based on the Earth Science interest of Dorset's Jurassic Coast: A consultation document from the Jurassic Coast Project, 1998. Dorchester.

Badman, T. 1994: Interpreting earth science sites for the public. Geological and Landscape Conservation. London.

Barrow, G. 1993: Environmental Interpretation and Conservation in Britain. Conservation in Progress. Chichester.

Bitgood, S. 1988: Introduction: Visitor Studies - 1988, Visitor Studies - 1988 Theory, Research and Practice. Proceedings of the First Annual Visitor Studies Conference. Jacksonville.

Boniface, P. B. and Fowler, P. J. 1993: Heritage and Tourism in 'the global village'. London.

Boo, E. 1990: Ecotourism: the potentials and pitfalls. Washington DC.

Butler, R. W. 1991: Tourism, environment, and sustainable development, Environmental Conservation 18-3. Cambridge.

Carvalho, C. N. de, Rodrigues, J. 2009: New Challenges with geotourism: Proceedings of the VIII European Geoparks Conference. Idanha-a-Nova.

Catana, M. M., Rocha, D. 2009: The role of the Educational Programs on Tourism Development of NaturteJo and Arouca GeoParks Proceedings of the VIII European Geoparks Conference. Idanha-a-Nova.

Cope, F. W. 1972: The Peak District. London.

Cope, F. W. 1976: Geology Explained in the Peak District. Newton Abbot.

Cossons, N. 1974: The Conservation of Industrial Monuments. Museums Journal 74-2. London.

Culshaw, M. G., Bell, F. G., Cripps, J. C and O'Hara, M. 1987: Aspects of geology in planning. Planning and Engineering Geology 4. London.

Durham County Council, 1994. County Durham Geological Conservation Strategy. Durham.

Geological Society. A Forum for Earth Heritage Conservation in the UK. London.

Gonggrijp, G. P. 1997: Unknown, unloved: Education, the basis for protection. Engineering geology and the environment. Rotterdam.

Gonsalves, P. S. 1987: Alternative tourism - the evolution of a concept and establishment of a network. Tourism recreation research 12-2. Indira Nagar.

Hall, C. M., Weiler, B. 1992: What's Special about Special Interest Tourism? Special interest tourism. London.

Ham, S. H. 1992: Environmental Interpretation: A Practical Guide for People with Big Ideas and Small Budgets. Golden.

Hamblin, R. J. O., Warwick, G. T., White, D. E. 1978: Geological handbook for the wrens nest national nature reserve. London.

Harris, H. 1972: Industrial Archaeology of the Peak District. Newton Abbot.

Harrison, L. C., Husbands, W. 1996: Practicing responsible tourism: international case studies in tourism planning, policy, and development. New York.

Himus, G. W., Sweeting, G. S. 1972: Elements of Field Geology. London.

Hose, T. A. 1994a: Interpreting Geology at Hunstanton Cliffs SSSI, Norfolk: a summative evaluation. High Wycombe.

Hose, T. A. 1994b: Telling the story of stone - assessing the client base. Geological and Landscape Conservation. London.

Hose, T. A. 1994c: Rockhounds Welcomed? unpublished paper to the Visitor Studies Association Annual Conference. Raleigh.

Hose, T. A. 1995a: Selling the story of Britain's stone. Environmental Interpretation 10-2. 
Hose T. A. 1996a: Interpreting geology at Hunstanton cliffs SSSI, Norfolk - A summative evaluation 176. Earth Heritage Site Interpretation in England; a review of principle techniques with case studies. Peterborough.

Hose, T. A. 1995b: Evaluating interpretation at Hunstanton. Earth Heritage 4-20.

Hose T. A. 1996c: Geotourism, or can tourists become casual rock hounds? Geology on your Doorstep. London.

Hose, T.A. 1996b: Interpreting Geology at Charmouth Heritage Coast Centre, Dorset: A Summative Evaluation 176. Earth heritage site interpretation in England; a review of principle techniques with case studies. Peterborough.

Hose, T. A. 1997a: Ludlow, geology and tourism (including a summary of a visitor survey of the reading the Rocks Exhibition). High Wycombe.

Hose T. A. 1997b: Geotourism - selling the Earth to Europe. Engineering Geology and the Environment. Rotterdam.

Hose T. A. 1998a: Selling coastal geology to visitors. Coastal defence and earth science conservation. London.

Hose, T. A. 1998b: Is it any fossicking good? or behind the signs - a critique of current geotourism interpretative media. Unpublished keynote paper to Irish geotourism conference. Belfast.

Hose, T. A. 2000a: European Geotourism - Geological Interpretation and Geoconservation Promotion for Tourists. Geological Heritage: Its Conservation and Management. Madrid.

Hose T. A. 2000b: European Geotourism - An overview of the promotion of geoconservation through interpretative provision. Symposium Zukunftsfähiger Geotourismus - Ein Baustein zur lokalen Agenda 21. Bad Urach.

Hose, T. A. 2003: Geotourism in England: A two-region case study analysis. Ph. D. thesis. University of Birmingham, Birmingham.

Hose T. A. 2005a: Geo-tourism - appreciating the deep time of landscapes. Niche Tourism: contemporary issues, trends and cases. Oxford.

Hose, T. A. 2005b: Landscapes of meaning: geotourism and the sustainable exploitation of the European geoheritage. Unpublished presentation and workshop (May, 2005) for the Institute of Geography, University of Lausanne. Lausanne.

Hose, T. A. 2006: Leading the field: a contextual analysis of the field-excursion and the field-guide in England. Proceedings of the Critical Issues in Leisure and Tourism Education Conference. High Wycombe.

Hose, T. A. 2007a: Geoconservation versus geo-exploitation and the emergence of modern geotourism. Geology cross-bordering the Western and Eastern European Platform. Szczecin.

Hose T. A. 2007b: Geotourism in Almeria province, southeast Spain. Tourism: an international interdisciplinary journal 55-3. Zagreb.

Hose T. A. 2008: Towards a history of Geotourism: definitions, antecedents and the future. The History of Geoconservation - Special Publication 300. London.

Keene, P. 1994: Conservation through on-site interpretation for a public audience. Geological and Landscape Conservation. London.

Komoo, I. 1997: Conservation geology: A case for the ecotourism industry of Malaysia. Engineering Geology and the Environment. Rotterdam.

Kotler, P., Haider, D. H., Rein, L. 1993: Marketing Places: Attracting investment, industry and tourism to cities, states and nations. New York.

Krippendorf, J. 1987b: The holiday makers: understanding the impact of leisure and travel. Oxford.

Lawson, J. D. 1973: New exposures on forestry roads near Ludlow. Geological Journal 8-2. DOI: 10.1002/gj.3350080206

Lawson, J. D. 1977: Mortimer Forest Geological Trail. London.

Light, D. 1995: Visitors' use of interpretive media at heritage sites. Leisure Studies 14. London. DOI: http://dx.doi.org/10.1080/02614369500390111

McKeever, P. J., Zouros, N., Margarete Patzak, M. 2010: The UNESCO Global Network of National Geoparks. European Geoparks Conference, 2010. Internet:

http://www.petrifiedforest.gr/Lesvos2010/preformated_fullPaper.doc (16.12.2010).

McKirdy, A., Threadgould, R. 1994: Reading the Landscape. London.

Miller, J. S. 1990: Increasing visitor education through a tiered approach to interpretation, Visitor studies: Theory Research and Practice 3. Columbus. 
Nature Conservancy Council, 1970: Wren's nest national nature reserve geological trail. London. Nature Conservancy Council, 1990: Earth science conservation in Britain: a strategy. Peterborough. Nixon, F. 1969: The industrial archaeology of the peak district. Newton Abbot.

Neves, R., Downie, C. 1967: Geological excursions in the Sheffield region. Sheffield.

Novelli, M. 2005: Niche Tourism: contemporary issues, trends and cases. Oxford.

O'Rourke, R. 1990: The global classroom: an international symposium on educational tourism. Christchurch. Oxenham, J. R. 1966: Reclaiming derelict land. London.

Page, K. N. 1992: Site Information Boards for Geological and Geomorphological SSSIs. Peterborough.

Page, K. N. 1994: Information signs for geological and geomorphological sites: basic principles. Geological and landscape conservation. London.

Page, K. N., Keene, P., Edmonds, R. P. H., Hose, T. A. 1996: Earth heritage site interpretation in England; a review of principle techniques with case studies 176. Peterborough.

Patzack, M. 2000: Developing a UNESCO Geoparks Programme: Feasibility Study. Paris.

Patzak, M. 2009: UNESCO and the Global Geoparks Network - geological heritage and the sustainable development worldwide. New Challenges with geotourism. Idanha-a-Nova.

Phillips, A. 1989: Interpreting the Countryside and the Natural Environment. Heritage Interpretation $1-$ The Natural and Built Environment. London.

Read, S.E. 1980: A prime force in the expansion of tourism in the next decade: special interest travel. Tourism Marketing and Managing Issues. Washington.

Richter, L. K. 1987: The search for appropriate tourism. Tourism recreation research 12-2. Indira Nagar.

Robinson, E. 1998: Tourism in geological landscapes. Geology Today 7/8. London.

Sharpe, G. W. 1982: An Overview of Interpretation. Interpreting the environment. New York.

Rutt, P. 1995: Panel Beating in Gerolstein. Environmental Interpretation 10-2. Golden.

Simpson, I. M. 1982: Rocks and Fossils - a geological field guide: The Peak District. London.

Slomka, T., Kicinska-Swiderska, A. 2004: Geoturystyka podstawowe pojęcia (The basic concepts of geotourism). Geoturystyka 1.

Stanley, M.F. 1993: The national scheme for geological site documentation. Earth science conservation in Europe. Oslo.

Stevens, C., Gordon, J. E., Green, C. P., Macklin, M. G. 1992: Conserving our landscape: evolving landforms and Ice Age heritage. Crewe.

Thomas, I. A., Prentice, J.E. 1994: A consensus approach: industry and geoscience at the National Stone Centre, UK. Geological and Landscape Conservation. London.

Toghill, P. 1972: Geological conservation in Shropshire. Journal of the Geological society of London 128. London.

Toghill, P. 1994: Involving landowners, local societies and statutory bodies in Shropshire's geological conservation. Geological and landscape conservation. London.

Wimbledon, W. A. P., Ishchenko, A. A., Gerasimenko, N. P., Karis, L. O., Suominen,

V., Johansson, C. E., Freden, C. 2000: Geosites - An IUGS initiative: science supported by conservation. Geological Heritage: its conservation and management. Madrid.

Ward, S. V. 1998: Selling Places: The marketing and promotion of towns and cities 1850-2000. London.

Wimbledon, W. A. 1996a: National site selection, a stop on the road to a European geosites list. Geologica Balcania 26-1.

Wimbledon, W. A. 1996b: GEOSITES - a new conservation initiative. Episodes 19.

Wimbledon, W. A. P., Ishchenko, A. A., Gerasimenko, N. P., Karis, L. O., Suominen,

V., Johansson, C. E., Freden, C. 2000: Geosites - an IUGS initiative: science supported by conservation. Geological Heritage: Its conservation and management. Madrid.

World Tourism Organisation, 1985. The role of recreation management in the development of active holidays and special interest tourism and consequent enrichment of the holiday experience. Madrid.

Wray, J. 1991: Interpreting geological sites. Earth science conservation 28. Belfast.

Wright, R. 1993: Conservation and landfill - a question of timing. Earth Science Conservation 32. Belfast.

Zouros, N. 2006: The European geopark network: geological heritage protection and local development a tool for geotourism development in Europe. $4^{\text {th }}$ European geoparks meeting. 